УДК 334

DOI: 10.35340/2308-104X.2019.83-2-07

\section{ЕКОНОМІЧНІ АСПЕКТИ РОЗВИТКУ ТА \\ ПРОЕКТУВАННЯ АГРАРНОГО \\ МАШИНОБУДУВАННЯ В УКРАÏHI}

\author{
ECONOMIC ASPECTS OF \\ AGRICULTURAL MACHINE \\ BUILDING DEVELOPMENT AND \\ DESIGN IN UKRAINE
}

\author{
ШПИЛЬОВА В. О., \\ доктор економічних наук, \\ професор, завідувач кафедри \\ економіки, фінансів, обліку i \\ аудиту Черкаської філії \\ Приватного вищого навчального \\ закладу «Свропейський \\ університет» \\ КОТЬКАЛОВА-ЛИТВИН І. В., \\ кандидат економічних наук, \\ доцент, доцент кафедри економіки \\ Приватного вищого навчального \\ закладу «Свропейський \\ університет»
}

\author{
SHPILOVA V., \\ Doctor of Economics, Professor, \\ Head of the Department of \\ Economics, Finance, Accounting \\ and Audit, \\ Cherkasy Branch of the Private \\ Institution of Higher Education \\ "European University" \\ KOTKALOVA-LITVIN I., \\ PhD in Economics, Associate \\ Professor, Department of Economics \\ Private Institution of Higher \\ Education "European University"
}

У статті розглянуто основні підходи до визначення сутності сільськогосподарського машинобудування та проведено їх узагальнення. Автором виокремлено окремі елементи, що здатні виступати стимулюючими чинниками розвитку та проектування новітнього створення підприємств сільськогосподарського машинобудування. $B$ результаті, у складі ичих чинників виокремлено економічні аспекти даних прочесів, щуо дозволяє сформулювати напрями відповідного ефективного фінансування та державної підтримки.

Ключові слова: аграрний бізнес; економічна ефективність; машинобудування; розміщення продуктивних сил; сільське господарство.

В статье рассмотрены основные подходы к определению сущчности сельскохозяйственного машиностроения и проведения их обобщения. Автором выделены отдельные элементы, способные выступать стимулируюшими факторами развития и проектирования нового создания предприятий сельскохозяйственного машиностроения. $B$ результате, в составе этих факторов выделень экономические аспекты данных прочессов, позволяет сформулировать направления соответствующего эффективного финансирования и государственной поддержки.

Ключевые слова: аграрный бизнес; экономическая эффективность; машиностроение; размещения производительных сил; сельское хозяйство. 
The article deals with the main approaches to the definition of the essence of agricultural machinery and their generalization. The author identifies some elements that can act as stimulating factors in the development and designing of the latest creation of agricultural machinery enterprises. As a result, among these factors, the economic aspects of these processes are identified, which allows formulating the directions of the corresponding effective financing and state support.

Keywords: agrarian business; economic efficiency; engineering; distribution of productive forces; agriculture.

Постановка проблеми. Основою будь-якого виробничого процесу є його матеріально-технічне та ресурсне забезпечення. Особливістю агробізнесу $\epsilon$ суттєвість та значимість компоненту землі у складі капіталу підприємства, при цьому, за відсутності належного техніко-технологічного забезпечення реалізація сільськогосподарського циклу неможлива. Технічне забезпечення агарного виробництва $є$ одним 3 вирішальних факторів продовольчої безпеки держави. Світовий досвід показує, що ті країни, які досягли значних успіхів у аграрному секторі мають потужні галузі сільськогосподарського машинобудування i високотехнологічні системи інженерно-технічного обслуговування. Це аксіома нормального функціонування будь-якого суспільства, що має відповідні для сільського господарства природно-кліматичні умови.

Спад обсягів виробництва і ефективності у вітчизняному аграрному секторі за роки незалежності зумовили макроекономічні трансформації політичного і соціально-економічного устрою нашої держави. Проведено корінні реформи в різних галузях народно господарського комплексу, змінено форму власності на землю, опрацьовано і прийнято важливі законодавчі акти розвитку національної економіки. Проте проблема інженерно-технічного забезпечення агропромислового виробництва через різні причини до цих пір у достатній мірі не вирішена.

Для розв'язання нелегкого завдання сталого розвитку аграрної сфери економіки іiі необхідно розглядати не ізольовано як окрему самостійну галузь, а як органічну складову цілісної макроекономічної системи. I відповідно їі ресурсний потенціал - як частку народногосподарського потенціалу.

Аналіз останніх досліджень $i$ публікацій. Питання технічного забезпечення аграрного виробництва досліджують вітчизняні і зарубіжні вчені та практики. Питання технічного забезпечення аграрного виробництва на основі інноваційно-інвестиційного розвитку досліджуються такими вченими: Булгаков В. М., Войтюк Д. Г., Даценко М. Д., Довжик М. Я., Зінь Е. А., Калашнікова Т. В., Козак Ю. Г., Кондратець В. О., Михайлюк О.Л., Семенов В. Ф., Ревенко М. В., Яцун С. С. та іншими. Питання щодо забезпеченості агарного сектору технічними засобами $є$ дискусійними i потребують більш глибокого дослідження.

Метою роботи є дослідження економічних передумов розвитку сільськогосподарського сегменту машинобудівної галузі в сучасних умовах розвитку країни. 
Виклад основного матеріалу дослідження. Технічне забезпечення сільського господарства досягло нині критичної межі, частка застарілої сільськогосподарської техніки в масштабах країни $\epsilon$ критично високою. Утримування технічного потенціалу на оптимальному рівні та ефективна організація його використання - одні 3 вирішальних чинників забезпечення сталого виробництва аграрної продукції, а отже, і продовольчої безпеки країни. Технічне оснащення аграрного виробництва на рівні технологічної потреби дозволяє якісно, швидко, в повному обсязі виконувати всі технологічні процеси й операції та виробляти продукцію з оптимальними витратами праці і коштів.

В Україні, й досі не вирішена проблема матеріально-технічного забезпечення аграрного виробництва, переробки та реалізації продукції, не досягнуто паритету цін на промислову та сільськогосподарську продукцію, що поставило товаровиробників останньої у важкі економічні умови, а недостатня державна підтримка, не врегульовані питання кредитування та інші важелі стимулювання виробництва i життя на селі дедалі погіршують ситуацію. Поняття машинобудування сільськогосподарської техніки можна розглядати 3 економічної точки зору та зі сторони технологічного процесу.

Наприклад, науковець В. О. Кондратець розглядає сільськогосподарське машинобудування як низку виробничих (сукупність окремих взаємопов'язаних процесів, необхідних для створення готової продукції шляхом переробки вихідних матеріалів) та технологічних процесів (частина виробничого процесу, яка безпосередньо пов'язана із зміною форм, розмірів і властивостей матеріалів або із складанням, обкаткою і випробуванням готових виробів) [7].

В економічній сфері сільськогосподарське машинобудування - особлива ланка господарства, яка спрямована на ефективне використання національних ресурсів за допомогою високотехнологічного виробництва, залучення капіталу та покращення стійкості вітчизняної продукції на міжнародному ринку. Також поняття виробництва сільгосптехніки в країні становить окрему галузь у системі цілісного господарства. Сільськогосподарське машинобудування - галузь машинобудування, що здійснює технічне переозброєння сільського господарства.

Булгаков В. М. та Даценко М. Д. 3 наукової точки зору вивчають сільськогосподарське машинобудування як ланцюг розв'язання задач, проведення науковотеоретичних i науково-практичних заходів, тобто проходження через низку етапів від розробки технічного завдання, коли сільськогосподарської машини ще фактично немає, а тільки накреслюються, вимальовуються в уяві iї науково опрацьовані обриси до розробки технічного завдання, далі - технічний проект, конструкторський проект, виготовлення дослідних зразків, низка випробувань, доробки і започаткування виробництва. Машинобудування визначається від початкового наукового опрацюванням до майбутньої сільськогосподарської машини та надходження її на виробництво [1].

Багато дослідників та авторів, характеризуючи сутність поняття сільськогосподарського машинобудування, відштовхуються від спрямованості використання продукції чи задоволення потреб споживачів. Як вважає Зінь Е. А., сільськогосподарське машинобудування - це сукупність промислових підприємств, що виготовляють машини, призначені для сільськогосподарських 
потреб. Підприємства випускають трактори, комбайни, жатки, сіялки, косарки, устаткування для тваринництва, машини для боротьби 3 шкідниками $\mathrm{i}$ хворобами рослин, збиральні та дощувальні машини тощо. Усі ці машини орієнтовані на їх використання у сільськогосподарському виробництві [4].

Розглядаючи машинно-технологічний комплекс сільського господарства як інноваційну базу аграрного виробництва, можемо іiі охарактеризувати як найважливішу систему, яка орієнтована на соціальну виробничу систему, регулює обсяги, якість i економічні характеристики кінцевої сільськогосподарської продукції та об'єднує агротехнології виробництва цієї продукції, виконувані машинними агрегатами, технічні засоби та інфраструктуру, що забезпечує працездатність системи. Агротехнології виробництва рослинницької і тваринницької продукції - це комплекс впливів на біологічний об'єкт, у результаті яких забезпечується отримання сільськогосподарської продукції 3 запроектованими кількістю, якістю та економічними параметрами [5].

Визначення машинобудівного агропромислового комплексу може характеризуватись також залежно від зацікавленості різних суб'єктів господарювання. 3 огляду на це, можна виділити державне значення сільськогосподарського машинобудівного комплексу та, виходячи 3 погляду зацікавленості окремих виробників сільгосптехніки, у розрізі вирішення певних цілей та задач, ступеня важливості.

Економічний механізм, який забезпечував би нормальне відтворення виробництва, знаходиться у фазі становлення, що надто затяглася. Значною мірою узурповано товарно-грошові відносини з боку посередницьких структур 3 метою привласнення прибутку сільськогосподарських товаровиробників.

В разі, коли не будуть терміново вжиті дієві економічні заходи щодо відтворення технічного потенціалу агропромислового комплексу, в Україні через 3 - 5 років може взагалі припинитися товарне виробництво багатьох видів сільськогосподарської продукції через повну деіндустріалізацію аграрного виробництва. Держава втрачає продовольчу незалежність. Наслідки від її втрати можуть бути більш руйнівними для країни, ніж енергетична залежність у газовій та нафтовій сферах. Втрата продовольчої безпеки загрожує втратою самої державності України.

Низька платоспроможність сільськогосподарських товаровиробників призвела до значного уповільнення темпів відтворення технічних засобів, внаслідок чого вітчизняні заводи тракторного і сільськогосподарського машинобудування майже повністю втратили ринки збуту своєї продукції $\mathrm{i}$ знаходяться на межі банкрутства та припинення виробництва технічних засобів для сільського господарства. 3 тих же причин практично втрачена ремонтнообслуговуюча галузь. Наявний парк машин підтримується у робочому стані в основному зусиллями самих користувачів на власній обслуговуючій базі, яка недостатньо забезпечена ремонтно-технічним обладнанням і кваліфікованими кадрами. Ці негативні процеси супроводжуються втратою робочих місць, відтоком кваліфікованих інженерно-технічних і робітничих кадрів, їх міграцією в інші галузі і навіть країни. 
Отже, першочерговим завданням держави $\epsilon$ створення умов, що забезпечать значне підвищення темпів відтворення технічного потенціалу аграрного виробництва, доведення технічного оснащення до рівня технологічної потреби.

Зменшення витрат енергоресурсів належить до основних чинників конкурентоспроможності аграрного виробництва. Тому важливим напрямом державної технічної політики в Україні має стати формування машиннотракторного парку аграрної сфери виробництва за рахунок вітчизняної конкурентоспроможної техніки. Особливого значення набуває підвищення якісних показників усіх видів і типів силових та робочих машин, збільшення не менш як удвічі тривалості роботи вітчизняних тракторів і комбайнів.

Незадовільний технологічний стан більшості організаційно-правових формувань, стрімкий процес фізичного i морального старіння машиннотракторного парку, низькі темпи оновлення основних засобів, насамперед їх активної частини, поступове зниження рівня технічного потенціалу стають головною проблемою розвитку сільськогосподарського виробництва і не дають змоги виробляти конкурентоспроможну продукцію.

На фоні загальних обсягів придбання техніки, постачання машин вітчизняного виробництва за 2001-2012 роки скоротилося від 60 до 25-30\%, тобто відбулося різке збільшення частки імпортної техніки.

Нині ввезення технічних засобів в Україну здійснюється різними виробниками чи дилерами безсистемно, без організації якісного сервісу на навчання кадрів. Значну частину імпорту становлять машини, що були в користуванні і сьогодні вже взагалі зняті з виробництва. Відсутній належний облік імпорту техніки.

Невід'ємною складовою формування й розвитку технічної політики $є$ створення інфраструктури ринку техніки і технічних послуг, організація мережі регіональних фірмових торговельно-технічних центрів, дилерсько-сервісних підприємств, прокатних пунктів, фірмових магазинів із реалізації технічних засобів і запасних частин. Тут важливу роль мають відіграти машинно-будівні заводи та машинно-технологічні об'єднання. В організації відновлення працездатності техніки, яка має високий рівень технічного зносу, особливого значення набуває створення надійної служби технічного сервісу. За умов дефіциту технічних засобів доцільно ширше розвивати вторинний ринок сільськогосподарських машин та обладнання.

Специфічні умови аграрного виробництва, серед яких важливе місце належить використанню природних факторів, істотні відмінності за сутністю і характером застосування технологічних операцій у різних виробничих галузях сільського господарства, необхідність щодо переміщення агрегатів на далекі відстані у процесі виконання робіт, формують відповідні вимоги щодо створення й експлуатації технічних засобів.

Слід підкреслити, що основою вирішення проблеми розробки системи машин має стати обгрунтування технологічних вимог до забезпечення комплексної механізації виробництва сільськогосподарської продукції. Розробка i серійний випуск системи машин повинні передбачати створення науково обгрунтованої сукупності технічних засобів для механізації 
сільськогосподарського виробництва, їхню високу пристосованість до умов експлуатації i, разом 3 тим, забезпечувати максимальну універсальність застосування, високу енергозаощадливість за доступної вартості для сільськогосподарських споживачів.

Неодноразові спроби створення системи машин, яка б включала повний набір силових i робочих машин для здійснення комплексної механізації сільськогосподарського виробництва, так і не досягли поставленої мети. Йдеться про незавершеність комплексної механізації технологічних процесів у виробництві переважної більшості видів сільськогосподарської продукції. На основі створених систем машин здебільшого розроблялись і впроваджувались технології виробництва певних видів сільськогосподарської продукції. За таких умов частина технологічних операцій залишилась для окремих регіонів поза можливостями використання технічних засобів.

Здійснення комплексної механізації аграрного виробництва потребує детального опрацювання технологічних процесів 3 урахуванням регіональних особливостей виробництва кожного виду сільськогосподарської продукції. Проте, як показала практика, тільки на основі розробки технологічних вимог здійснення комплексної механізації виробничих процесів створюється реальна можливість формування необхідної для технологічного переоснащення системи машин. При цьому слід обов'язково враховувати вимогу забезпечення оптимальних строків, високої якості виконання та дотримання норм використання технологічних матеріалів у разі здійснення технологічних операцій. Тут мають бути враховані допустимі рівні пошкодження рослин при догляді за посівами, витрати технологічних матеріалів і втрат врожаю. Потрібно визначити оптимальну продуктивність агрегатів і питомі енергетичні витрати на виконання робіт. Зважаючи на різке зниження родючості грунту, новостворювані технічні засоби не повинні перевищувати оптимальні параметри техногенного навантаження на грунтовий покрив, що призводить до надмірного ущільнення або пошкодження поверхневого родючого шару. При формуванні системи машин важливо передбачати можливості досягнення оптимальних параметрів машинно-тракторного парку в сільськогосподарських підприємствах 3 урахуванням дотримання технологічних вимог, якісного виконання передбачених обсягів механізованих робіт в оптимальні строки. При цьому необхідно прагнути до забезпечення пропорційного поєднання силових i робочих машин, спрямованого на раціональне завантаження їх виробничих потужностей.

Отже, необхідно створити ефективні економічні механізми, які мають забезпечити значне збільшення обсягів інвестицій у технічне переоснащення аграрного сектору. Основними джерелами таких надходжень можуть бути:

- власні кошти сільськогосподарських підприємств, зокрема амортизаційні відрахування, прибуток та спеціальні заощадження, спрямовані на конкретні завдання;

державні дотації (3 державного i місцевого бюджетів) сільськогосподарським товаровиробникам на придбання техніки шляхом компенсації їм частини вартості техніки, передусім, тракторів і комбайнів; 
- довгострокові кредити комерційних банків на придбання насамперед складної техніки з компенсацією частини відсотків за кредити з державного або місцевого бюджетів;

- кошти фінансових лізингових фондів, створених за участю державного i місцевого бюджетів, заводів-виробників техніки і сервісних технологічних центрів, інвесторів.

Виробництво конкурентоспроможної сільськогосподарської продукції в сучасних умовах неможливе без машин, за допомогою яких здійснюються основні технологічні процеси. Для отримання максимальних обсягів продукції при заданому ресурсному потенціалі аграрного підприємства у тій чи іншій природно-економічній зоні необхідно, щоб вони виконувалися згідно з науково обгрунтованими агрозоотехнічними вимогами. Усіляке відхилення від цих умов, у тому числі за рахунок погіршення стану машин та їх відмов, а відтак якості виконання робіт та зупинок технологічних процесів, призводить до недовипуску і втрати продукції.

Висновки $i$ перспективи подальших досліджень. Сільськогосподарське машинобудування $є$ невід'ємною частиною одночасно і сектору промисловості, $\mathrm{i}$ сектору сільського господарства. Державна технічна політика $є$ складовою інноваційно-інвестиційної політики і на сучасному етапі іii формування та реалізації передбачає обгрунтування технологічних вимог щодо комплексної механізації виробничих процесів, створення системи машин, спроможної забезпечити розвиток конкурентоспроможного сільськогосподарського виробництва, визначення інвестиційних пріоритетів для оновлення й розвитку матеріально-ресурсної бази, створення ринку технічних засобів аграрного сектору економіки.

Держава законодавчими та економічними важелями повинна сприяти залученню до лізингової діяльності банків, спеціалізованих фінансових організацій, виробників техніки, незалежних лізингових компаній та приватного капіталу. Основні економічні аспекти розвитку даної галузі уособлюють у собі передумови та стимулюючі чинники розвитку агробізнесу та його технічного забезпечення.

\section{Лimepamypa:}

1. Булгаков В. М., Даценко М. Д. Основні напрями наукового забезпечення механізації сільського господарства та сільськогосподарського машинобудування. Вісник Дніпропетровського державного аграрного університету. 2009. № 2: Сучасні проблеми землеробської механіки. С. 11-16.

2. Войтюк Д. Г., Яцун С. С., Довжик М. Я. Сільськогосподарські машини: основи теорії та розрахунку: навч. посіб. для студ. аграрних вищ. закл. освіти III-IV рівнів акредитації зі спец. «Механізаціясільськогогосподарства. Суми: Університетська книга, 2008. С. 1-3.

3. Довідка щодо сільського господарства України в умовах COT. URL: http://www.me.gov.ua/control/uk/publish/ article?art_id=139215\&cat_id=38231.

4. Зінь Е. А. Регіональна економіка. К.: «Видавничий дім «Професіонал», 2008. С. 179-183. 
5. Ковалевський В. В., Михайлюк О. Л., Семенов В. Ф. Розміщення продуктивних сил і регіональна економіка. К.: Знання, 2006. С. 195.

6. Козак Ю. Г., Ковалевський В. В. Міжнародні організації: навч. посібник. Київ: ЦУЛ, 2007. С. 135.

7. Кондратець В. О. Автоматика та автоматизація виробництва сільськогосподарських машин. К.: Вища школа, 1993. С. 5-7.

8. Калашнікова Т. В. Механізм і пріоритети державної підтримки аграрного сектору економіки. Економіка АПК. 2012. №8. С. 100-104.

9. Ревенко М. В. Удосконалення державного регулювання розвитку аграрного сектору економіки. Економіка Украӥни. 2011. №12. С. 51-55.

\section{References:}

1. Bulgakov V. M., Dacenko M. D. (2009).Osnovni napryamy` naukovogo zabezpechennya mexanizaciyi sil`s`kogo gospodarstva ta sil`s`kogospodars`kogo mashy`nobuduvannya. Visny`k Dnipropetrovs`kogo derzhavnogo agrarnogo universy `tetu. issn.2: Suchasni problemy`zemlerobs`koyi mexaniky`.

2. Vojtyuk D. G., Yaczun S. S., Dovzhy`k M. Ya. (2008) Sil`s`kogospodars`ki mashy`ny`: osnovy` teoriyi ta rozraxunku: navch. posib. dlya stud. agrarny`x vy`shh. zakl. osvity` III-IV rivniv akredy`taciyi zi specz. «Mexanizaciyasil`s`kogogospodarstva. Sumy`: Universy`tets`ka kny`ga.

3. Dovidka shhodo sil`s`kogo gospodarstva Ukrayiny` v umovax SOT available at: http://www.me.gov.ua/control/uk/publish/ article?art_id=139215\&cat_id=38231.

4. Zin` E. A. (2008) Regional`na ekonomika. K.: «Vy`davny`chy`j dim «Profesional».

5. Kovalevs`ky`j V. V., My`xajlyuk O.L., Semenov V.F. (2006) Rozmishhennya produkty`vny`x sy`l i regional`na ekonomika. K.: Znannya.

6. Kozak Yu. G., Kovalevs`ky`j V. V. (2007) Mizhnarodni organizaciyi: navch. posibny`k. Ky`yiv: CzUL.

7. Kondratecz` V. O. (1993) Avtomaty`ka ta avtomaty`zaciya vy`robny`cztva sil`s`kogospodars`ky`x mashy`n. K.:Vy`shha shkola.

8. Kalashnikova T. V. (2012) Mexanizm i priory`tety derzhavnoyi pidtry`mky`agrarnogo sektoru ekonomiky`Ekonomika APK.

9. Revenko M. V. (2011) Udoskonalennya derzhavnogo regulyuvannya rozvy`tku agrarnogo sektoru ekonomiky`/ Ekonomika Ukrayiny`.

The article considers the main approaches to the definition of the essence of agricultural machinery and their generalization. The basis of any production process is its logistical and resource support. The peculiarity of agribusiness is the significance and significance of the land component in the capital of the enterprise, while, in the absence of proper technical and technological support, the implementation of the agricultural cycle is impossible. Technical support for agrarian production is one of the decisive factors of food security of the state. World experience shows that those countries that have achieved significant success in the agricultural sector have 
powerful branches of agricultural machinery and high-tech engineering and maintenance services.

The author highlights individual elements that can act as stimulating factors for the development and designing of a new creation of agricultural machine-building enterprises. The definition of machine-building agro-industrial complex can also be characterized depending on the interest of different subjects of management. In view of this, it is possible to highlight the state significance of the agricultural machinebuilding complex and, given the interest of individual producers of agricultural machinery, in terms of solving certain goals and objectives, the degree of importance.

An economic mechanism that would ensure the normal reproduction of production, is in the phase of formation, which is too late. To a large extent, commodity-money relations have been usurped by the intermediary structures with the aim of appropriating the profits of agricultural producers.

As a result, the economic aspects of these processes are identified as part of these factors, it allows us to formulate the directions of the corresponding effective financing and state support. Agricultural engineering is an integral part both in the sector of industry and the agricultural sector. State technical policy is an integral part of innovation and investment policy, and at the present stage of its formation and implementation the justification of technological requirements for the complex mechanization of production processes, creation of a system of machines capable of ensuring the development of competitive agricultural production, identifying investment priorities for updating and developing the material and resource base, creation of a market for technical means of the agrarian sector of the economy.

State legislative and economic leverage should facilitate the leasing activities of banks, specialized financial organizations, technology manufacturers, independent leasing companies and private capital. The main economic aspects of the development of this industry embody the preconditions and stimulating factors for the development of agribusiness and its technical support. 